Perhaps Hughes and colleagues should try this management in their patients with difficult asthma.

Russells Hall Hospital,

MICHAEL BONE

Dudley,

West Midlands DY1 $2 \mathrm{HQ}$

1 Hughes JR, Higgins EM, du Vivier AWP. Acne associated with inhaled glucocorticosteroids. BMF 1992;305:1000. (24 October.)

2 Bone MF, Kubik MM, Keaney NP, Summers GD, Connolly CK, Sherwood Burge P, et al. Nedocromil sodium in adults with asthma dependent on inhaled corticosteroids: a double with asthma dependent on inhaled corticosteroids:
blind, placebo controlled study. Thorax 1989;44:654-9.

3 Haas JF, Staudinger HW, Schuijt C. Asthma deaths in New Zealand. BMF 1992;304:1634.

\section{GPs and health and safety at work}

EDITOR,-R A Cooke and E S Hodgson draw attention to some major concerns regarding health and safety at work in general practice.' These have been given added piquancy by the $£ 750$ fine imposed on a senior partner of an English practice for contravening health and safety regulations.

Cooke and Hodgson advise against using glutaraldehyde in the surgery, and we support this view. General practitioners may well consider buying a portable steam steriliser (desk top autoclave) to replace the hazardous, but fairly reliable, disinfectants of the aldehyde group and must be aware of the implications. Steriliser vessels contain steam under pressure and should be insured against third party liability. ${ }^{3}$ The instruments should be inspected regularly (the statutory interval is 14 months) by a competent person, usually an insurance company engineer. We doubt if an employer's normal liability policy would cover an accident with an autoclave. A recent postal survey of 208 general practitioners in Fife produced a response from 138,71 of whom owned or were responsible for a portable steam steriliser. Only 21 of these owners had a specific insurance policy for their instrument.

We strongly recommend that anyone considering buying a portable steam steriliser should consult a document from the NHS Procurement Directorate, which clearly states the requirements. ${ }^{3}$ Buying, commissioning, and correctly using an autoclave entail considerable capital outlay, a thorough understanding of the principles involved, and tenacity.

ANDREW WHYTE

CHRIS FOX

Fife Area Laboratory

Department of Medical Microbiology,

Kirkcaldy,

Fife KY2 5AG

1 Cooke RA, Hodgson ES. General practitioners and health and safety at work. $B M 7$ 1992;305: 1044. (31 October.)

2 Doctor fined after boy, 2, drank acid. Independent 1992 November $4: 4$.

3 NHS Procurement Directorate. A further evaluation of transpor able steam sterilisers for unwrapped instruments and utensils. London: HMSO, 1990. (Health equipment information 196.)

4 Whyte AS, Fox C, Ferguson S. Sterile instruments for minor operations in general practice. $\mathrm{Br} \mathcal{F}$ Gen Pract (in press).

EDrrok,-I endorse R A Cooke and E S Hodgson's sentiments regarding general practitioners' poor awareness of health and safety regulations.' By way of mitigation, though, general practitioners face the same problems as any other small business in this respect-namely, lack of any obvious source of comprehensive advice on health and safety in the workplace. Though occasional articles relating to specific health and safety topics have been published in magazines for general practitioners, ${ }^{2}$ these have failed to stimulate general practitioners to give health and safety at work equal priority with some of the more trendy issues, such as practice audit, health promotion clinics, and immunisation targets, which are both supported by family health services authorities and driven by remuneration.

It is perhaps unrealistic to expect general practices individually to investigate the requirements of disparate health and safety regulations, such as the Electricity at Work Regulations, the Control of Substances Hazardous to Health Regulations, the Reporting of Injuries, Diseases and Dangerous Occurrences Regulations, ${ }^{\dagger}$ and First Aid at Work Regulations. A far more effective approach would be for individual family health services authorities to prioritise health and safety issues, issue comprehensive guidelines on all aspects to their general practitioners in an easily read handbook, and encourage the incorporation of health and safety issues into educational meetings approved for the postgraduate education allowance. Such an initiative is currently being developed by Leicestershire Family Health Services Authority as part of the European year of safety and health at work.

S J MOORE

Empingham Medical Centre

Empingham,

Oakham,

Rutland LE15 8PR

1 Cooke RA, Hodgson ES. General practitioners and health and safety at work. BMf 1992;305:1044. (31 October.)

2 Paimer K. Health and safety in the surgery. Practitioner 1992; 236:705

3 Stubbs D, Buckle P. Back and upper limb disorders. Practitioner 1992;236:34.

4 Health and Safety Executive. Reporting of imjuries, diseases and dangerous occurrences regulations 1985. London: HMSO, 1985.

\section{Assisted conception on the NHS}

EDITOR,-In writing on NHS funding for assisted conception services $M$ G Chapman rightly highlights the issue of rationing services but misrepresents the way in which purchasing decisions are made.' The real questions are about the provision of services within the NHS. Staff working in assisted conception units and infertile couples inevitably consider assisted conception services to be of high priority. Purchasers rank the priority of these services differently since they have to take into account the many competing demands on the health service. Nevertheless, Chapman's assertion that district purchasers "do not see infertility as a priority" is incorrect.

It is not the case that purchasing decisions are taken by a few people behind closed doors. The NHS reforms allow decision making to be made explicit, as illustrated by the debate about public accountability of purchasers and health authorities. Open decision making is surely an advance on the implicit rationing that clinicians made in the past. It is ironic that clinicians had the power to shift resources from relatively ineffective tubal surgery to the more effective in vitro fertilisation but failed to do so. This change is now occurring as a consequence of purchasers' decisions on the relative effectiveness and cost of services.

The idea that patients would have the power to choose and that money would follow them was always just political rhetoric. The NHS reforms are about using resources more effectively-even if that means shifting power from hospitals.

Ours is one of the health authorities that purchase in vitro fertilisation from Guy's Hospital, and this arrangement was not materially affected by the NHS reforms. In a public health authority meeting we recently agreed to purchase cycles of in vitro fertilisation from King's Healthcare, and we will be publishing a consultation document on all subfertility services for our residents.

Others have pointed out that the central problem in subfertility services is how to use resources as effectively as possible in the light of what is known about the effectiveness of different interventions. ${ }^{2}$
To focus on assisted conception techniques alone is unhelpful as it distracts attention from this more difficult task.

South East London Commissioning Agency,

GRAHAM BICKLER

London SE1 9RY

1 Chapman MG. Assisted conception on NHS. BMF 1992;305: 772. (26 September.)

2 Setchell M, Howell R. Assisted conception on NHS. BMF 1992 305:771-2. (26 September.)

The management of subfertility. Leeds: School of Public Health, Leeds University, 1992. (Effective health care bulletin No 3 .)

\section{Education is promotion}

EDrToR,-The EC directive $92 / 28 / \mathrm{EEC}$ on the advertising of medicinal products for human use will require the BMJ Publishing Group to change its wording relating to sponsored supplements. ${ }^{12}$ From next January all industry sponsored symposiums attended by those who prescribe or supply drugs will be classed as promotional, and by extension so too will the publication of such meetings. Accordingly, the permitted line from the sponsoring company will have to read: "Publication of this supplement is made possible by a promotional grant from. ...'

This change in classification will have additional, and perhaps more profound, effects. As such grants are treated as promotional the company will no longer be able to set them against profit targets when negotiating within the Pharmaceutical Price Regulation Scheme, and industry's benevolence in "education" will inevitably shrink.

Clinical Pharmacology Unit,

JOE COLLIER St George's Hospital Medical School, London SW $170 \mathrm{RE}$

Kingman S. Symposiums published without peer review. $B M J$ 1992;305:1049. (31 October.)

2 Council directive 92/28/EEC of 31 March 1992 on the advertising of medicinal products for human use. Official Yournal of the European Communities. 1992;L113:13-8.

\section{Nitrous oxide, nitric oxide, and neurotransmission}

EDITOR,-Bernard Dixon seems to believe that nitric oxide is the first simple organic molecule to be shown to have a role in neurotransmission. This has become a popular misconception.

In 1981 Lichtigfeld and I proposed that a simple organic molecule, a gas, could be active in neurotransmission. ${ }^{2}$ This was long before such a role was postulated for nitric oxide. ${ }^{3}$ Shortly after our suggestion ${ }^{2}$ the endogenous gas oxygen and the exogenous gas nitrous oxide were shown to influence neurotransmission directly at opioid receptors. ${ }^{+}$These findings were later confirmed independently. ${ }^{5}$

Although it would be incorrect to confuse nitrous oxide with nitric oxide, it seems that they are more similar than Dixon would have us believe.

MARK A GILLMAN

South African Brain Research Institute,

Waverley 2090,

Johannesburg,

South Africa

1 Dixon B. Nitric oxide goes centre stage. BMf 1992;305:779. (26 September.)

2 Gillman MA, Lichtigfeld FJ. A comparison of the effects of morphine sulphate and nitrous oxide analgesia on chronic pain morphine sulphate and nitrous oxide ana

3 The role of gases in neurotransmission [editorial]. South African fournal of Science 1991;87:573.

4 Daras C, Cantrill RC, Gillman MA. '(H)-Naloxone displacement: evidence for nitrous oxide as opioid receptor agonist. Eur $\mathfrak{f}$ Pharmacol 1983;89:177-8.

5 Ori C, Ford-Rice F, London E. Effects of nitrous oxide and halothane on mu and kappa opioid receptors in guinea-pig brain. Anesthesiology 1989;70:541-4 